\title{
Indigenous Peoples' Struggle for Secure Land Tenure in the Philippines: Case Study of Higaonon Tribe in Opol, Mindanao
}

\author{
Petr Drbohlav $^{1} \&$ Jiri Hejkrlik $^{1}$ \\ ${ }^{1}$ Department of Economics and Development, Faculty of Tropical AgriSciences, Czech University of Life \\ Sciences, Prague, Czech Republic \\ Correspondence: Jiri Hejkrlik, Department of Economics and Development, Faculty of Tropical AgriSciences, \\ Czech University of Life Sciences, Prague, Kamycka 129, 16500 Prague 6 - Suchdol, Czech Republic. Tel: \\ 420-2-2438-2508. E-mail: hejkrlik@ftz.czu.cz
}

\author{
Received: March 24, $2017 \quad$ Accepted: May 11, $2017 \quad$ Online Published: June 23, 2017 \\ doi:10.5539/ass.v13n7p38 URL: https://doi.org/10.5539/ass.v13n7p38
}

\begin{abstract}
Indigenous peoples worldwide struggle for control over land and natural resources against encroachment of state interests, external development and commercial pressures such as agribusiness, dams, logging and mining. Their battle to protect land and natural resources is at the same time the struggle to preserve indigenous culture and traditions often inextricably linked to the land itself. The Philippine Indigenous Peoples Rights Act recognizes the indigenous peoples' rights to their ancestral lands and domains and offers a way of improving their land tenure security. The article employs case study design to illustrate the implementation gap between the rights of indigenous peoples in law and practice and the role different stakeholders play in securing indigenous peoples' land tenure and dealing with palm oil agribusiness and mining industries' interests in ancestral domains on the case of Higaonon tribe in Misamis Oriental province, Mindanao. The methodology for data collection was focus group discussions and key informant interviews with representatives of tribal leaders and members, non-government organizations and government bodies. Our results indicate that conflicting laws and mandates of various government bodies and lack of coordination between them, as well as lack of resources and political will to implement the Indigenous Peoples Rights Act are important factors behind slow issuance of ancestral domain titles. At the same time, we show that significant factor in the land tenure insecurity of indigenous peoples is disunity within the tribe and conflicting interests of its members and clans used by companies to further enhance their business interests.
\end{abstract}

Keywords: land grabbing, indigenous peoples, ancestral domain, agribusiness, palm oil, mining

\section{Introduction}

Indigenous people worldwide struggle for control over what they claim as their land and their natural resources. In the times of globalization, they encounter encroachment of state interests, external development and commercial pressures such as large-scale agribusiness, logging and mining into their traditional lands. This accelerates deforestation and exploitation of natural resources in what has remained from their ancestral domains after the colonial period during which indigenous peoples had lost vast amounts of their ancestral lands. Uprooting of indigenous peoples from their land denies them the right to life and identity; their battle to protect land and resources is implicitly the struggle to preserve indigenous culture and traditions often inextricably linked to the land itself. As shown by Göcke (2013), Perera (2009), Carino (2009) and many others, the loss of land has also led to social, political and economic marginalization; indigenous peoples have become disadvantaged by almost every standard compared to the dominant society - including income, education, housing, health, and life expectancy.

Having developed from very different historical origins, modern legal systems and indigenous customary laws often contradict each other in their land tenure concepts (Molintas, 2004; Carino, 2012; Arquiza, 2005). Lands that governments claim as idle, marginal and uncultivated and therefore target for land concessions, investment or development are in reality often existing agricultural lands in ancestral domains where various customary land tenure arrangements are already in place (White et al., 2012; Borras \& Franco, 2011; Schneider, 2011; Scoones et al., 2013; AFRIM, 2011).

The legal concept of indigenous rights in international law represents recognition for indigenous peoples' 
collective rights to land and livelihood strategies within nation-state structures that have discriminated against them (Perera, 2009). Several countries, including the Philippines, Malaysia and Cambodia, have recognized indigenous land rights in their national legislations and have introduced corresponding domestic legal instruments to protect communal land rights and resources. However, despite these legal instruments, indigenous peoples are still disadvantaged because the lack of political motivation to properly enforce these laws or produce the regulations for implementing them impedes their full realisation (Xanthaki, 2003; Simbolon, 2009; Inman, 2016; O’Faircheallaigh, 2012; Novellino, 2000).

Indigenous land rights in the Philippines have attracted surprisingly relatively little interest from international development scholars despite the increased pressure on indigenous peoples' land and natural resources in recent years fuelled by the global land rush and ongoing armed conflicts. This paper strives to contribute to the renewed policy discussion on failures in the Indigenous Peoples Rights Act (IPRA) implementation and delays in its enforcement brought to spotlight by the Philippine president Rodrigo Duterte. This paper, using a case study design, aims to show that the mere existence of a domestic legal framework towards the rights of indigenous peoples in the Philippines does not ensure indigenous peoples' land tenure security vis a vis agribusiness and mining industry. Two main objectives of this paper could be described as to:

a) illustrate implementation gap between the rights of indigenous peoples in law and practice and significant delays in land titling under IPRA and explore reasons behind these gaps and delays

b) explore roles of different stakeholders such as indigenous communities and their tribal councils and farmers' organizations, non-governmental organizations (NGOs) and various government agencies in the process of securing Certificates of Ancestral Domain Titles (CADT); and the interaction between them and commercial interests in ancestral domain.

This study examines the land related conflicts in Opol municipality, Misamis Oriental province. The ancestral domain was brought to the public attention by several advocacy NGOs after a controversial oil palm plantation started operating here in 2011. These organizations, including Pesticide Action Network Asia and the Pacific (PAN AP), Rural Missionaries of the Philippines, Peasant Movement of the Philippines (KMP), Kalumbay Regional Lumad Organization, Sentro Kitanglad, and the Asian Peasant Coalition, organized International Fact Finding Mission in May 2012 and were active in campaigning on this particular land grabbing issue well into 2013.

The paper is structured in following way - the next section focuses on issues around indigenous peoples and the corresponding legal framework related to land tenure in the Philippines and provides literature overview of palm oil and mining industries' impact on local communities, especially indigenous peoples, with special emphasis on the Philippines. The third section provides the description of our case study area and the methodology employed. The fourth section then presents the results combined with discussion on the role of the state, NGOs and private businesses in indigenous peoples' land alienation, tribal unity and the disparity between the legal framework and its implementation.

\section{Indigenous peoples' land tenure and impact of mining and palm oil industries}

\subsection{Indigenous peoples and land tenure framework in the Philippines}

Estimated 10 to $15 \%$ of the Philippine population belongs to distinct indigenous communities who retain a close link with their traditions, have a special relationship with their ancestral land, territory and resources and their livelihoods tend to be subsistence-oriented (Molintas, 2004; Carino, 2012). In the 1970s pressure upon indigenous communities' land base, rich in natural resources, intensified as the national economy became increasingly foreign-dominated and export-oriented; as a result, indigenous communities have been besieged by a growing number of corporations engaged in mining, logging, plantations, and other export industries (Molintas, 2004; USAID, 2011). Indigenous peoples are among the poorest and most marginalized sectors of Philippine society experiencing neglect and discrimination in the provision of basic social services by the government (Carino, 2012; Rey, 2010).

What essentially distinguishes the indigenous peoples from the rest of the Philippine population is their concept of land and everything connected to it as granted and entrusted by one Creator/deity for everyone to harness, cultivate, sustain, and live on. Because of this divine origin of land, it is sacred and thus not subject to ownership, sale, purchase or lease. The adoption of a contemporary, Western model of land ownership that favours individual property rights and formal legal land titles is at odds with customary systems in which land is collectively held and inherited by communities and managed under the leadership of chieftains or datus (Bolton \& Leguro, 2015; IOM \& World Bank, 2013; Carino, 2012; Molintas, 2004). The superimposition of colonial laws started with a legal fiction, the so-called Regalian Doctrine, which declared that the Crown of Spain owned 
all lands in the archipelago by virtue of conquest. This would later become the theoretical bedrock upon which Philippine land laws were based; the 1894 Maura Law denied and contradicted customary land tenure laws by declaring that any lands not titled in 1880 would revert to the state (Molintas, 2004; Lynch, 2005). The Regalian Doctrine remained in favour throughout the American administration of the Philippines, providing legal justification for controlling the islands' natural resources (Crisologo-Mendoza \& Prill-Brett, 2009; Tujan, 2002; Rey, 2010; Lynch, 2005) - the 1905 Mining Law gave the Americans the right to acquire public land for mining purposes and enabled extraction of mineral resources from the indigenous territories. Among post-colonial pieces of legislation that would further deprive the indigenous peoples of their ancestral lands, was the 1975 Revised Forestry Code which provided that all land with a slope of 18 degrees or more is a public land (GoP, 1975); the indigenous peoples have traditionally practiced sustainable agriculture on such slopes in their ancestral territories (Molintas, 2004).

The passage of a landmark legislation for indigenous peoples in 1997, the Indigenous Peoples Rights Act (IPRA), has increased the prospects for sustaining communal land management in indigenous areas of the Philippines. This Act recognizes the indigenous peoples' rights to their ancestral lands and domains, sets forth the concept of communal/collective land ownership and is offering a way for securing land tenure to indigenous communities (Crisologo-Mendoza \& Prill-Brett, 2009; Arquiza, 2005). However, the U.N. Special Rapporteur on the Situation of Human Rights and Fundamental Freedoms of Indigenous Peoples observed inadequate implementation of this Act, particularly because it conflicts with other laws such as the 1995 Mining Act (UN, 2003). The existence of multiple government agencies charged with land administration and their different regulatory systems and instruments, as well as lack of coordination between them and local government units result in competing and overlapping tenures, when different agencies may issue tenurial instruments to different parties for the same parcel of land, based on each agency's respective mandate (Bolton \& Leguro, 2015; Llanto \& Ballestredos, 2003; Novellino, 2000).

IPRA led to the creation of the National Commission on Indigenous Peoples (NCIP), which has the mandate to implement the law and is the final authority in the issuance of ancestral domain land titles (GoP, 1997). IPRA defines ancestral domains as areas belonging to indigenous peoples and that are necessary to ensure their economic, social and cultural welfare. Ancestral domains comprise of lands, inland waters, coastal areas and natural resources occupied or possessed by indigenous people communally since time immemorial, continuously... except when interrupted by war, force majeure, displacement or as a consequence of government projects or voluntary dealings between government and private individuals/corporations (GoP, 1997). However, the ancestral domain certification process is being criticised because of its incorrect assumptions that all those interested in applying for titles are literate and able to grasp Western legal practices as well as have the financial means and time to go through these relatively costly procedures; many indigenous peoples are not aware that there is such a thing as land titling at first place (Foster, 2012; Molintas, 2004).

A significant safeguard provided by IPRA is the incorporation of the principle of 'free, prior and informed consent' (FPIC) requiring consent from indigenous communities prior to actions that affect their land and resource rights such as logging, mining, multipurpose dams, agribusiness plantations and other development projects. IPRA defines it as the "consensus of all members of the indigenous cultural communities/indigenous peoples to be determined in accordance with their respective customary laws and practices free from any external manipulation, interference, coercion and obtained after fully disclosing the intent and scope of the activity, in a language and process understandable to the community" (GoP, 1997). Various issues have been documented against the FPIC process citing among other problems allegations of manipulation, bribery and serious violations of the rights of indigenous peoples to pave way for economic activities (Doyle \& Carino, 2013; UN, 2003; Goodland \& Wicks, 2008; Doyle et al., 2007; Whitmore, 2006). The review of 34 FPIC cases in three Philippine regions, incl. Mindanao, conducted by GIZ found that less than $50 \%$ of the studied cases attained the status of full and faithful compliance with the FPIC Guidelines and procedures and a substantial number (38.2\%) of cases reported incidents of violations in the actual conduct of the FPIC (Calde et al., 2013).

\subsection{Negative impact of palm oil agribusiness on indigenous people}

Governments, multilateral funding institutions and the private sector, including banks, support and promote mainly the large-scale, agro-industrial model of palm oil production; palm oil sector has become one of the fastest growing mono-cropping plantations in the tropics because of its high yield per hectare and low production costs (Tauli-Corpuz \& Tamang, 2007). The palm oil industry is a growing sector also in the Philippines propelled by the increase in demand both domestically and internationally. It was labelled as a 'sunshine' priority industry under the Philippine Development Plan 2011-2016 and it is a major contributor in fulfilling the Philippine government's biofuel targets and seen as "peace-dividend development opportunity" for Mindanao (GoP, 2015; 
AFRIM, 2011).

The literature on oil palm cultivation confirms to large extent the environmental narrative of oil palm expansion as endangering both the environment and local communities as it comes with serious social, economic and environmental costs with adverse impacts on indigenous peoples, forest-dwellers and forests. Research from countries such as Sierra Leone, Colombia and Ghana has shown that large areas of land and forest traditionally used by indigenous peoples have been expropriated (Yengoh \& Armah, 2015; Maher, 2014; Schoneveld et al., 2011). This phenomenon is also particularly frequent in South-East Asian countries with weak land tenure regimes (Hall, 2011; Prachvuthy, 2011). Agribusinesses do not grow oil palm organically which means that the use of chemical-based inputs may pollute watersheds in ancestral domains and affect water supplies in the lowlands (Villanueva, 2011). The expansion of large-scale oil palm plantations in Indonesia has resulted in extensive deforestation as shown for example by Carlson et al. (2012), Lee et al. (2014), Sandker et al. (2007) and Obidzinski et al. (2012). The promoters of oil palm plantations claim that the industry will reduce unemployment and alleviate poverty; yet these claims are highly contested (for example Sandker et al., 2007; Obidzinski et al., 2012; Sokhannaro, 2011; Schoneveld et al., 2011; Selvadurai et al., 2013). Religious, sacred, burial and historical sites of indigenous peoples are destroyed because of oil palm expansion as was the case of Dayaks in Kalimantan (Potter, 2012) and as documented by NGOs on cases from Indonesia, Palawan island of the Philippines, Liberia or Colombia (Friends of Earth, 2008; Survival International, 2011; Global Witness, 2016; Environmental Investigation Agency, 2015).

\subsection{Mining industry, local communities, and indigenous peoples}

Foreign and domestic investment in mining has been encouraged by successive Philippine governments as an important source of revenue (Doyle et al., 2007; Tujan, 2002; Christian Aid, 2004). In 1995, a revised Mining Act was enacted to make it easier for foreign investors to obtain mining permits (Foster, 2012; Tujan, 2002).

Mining industry demands a significant amount of area to operate which makes it extremely challenging to coexist with the indigenous people of surrounding communities who depend largely upon the land for their livelihoods (Hilson, 2002). Physical displacement, relocation and resettlement induced by mining industry are widely acknowledged as posing enormous risks to mining-affected communities (Owen \& Kemp, 2015). As shown by Whitmore (2006) on several examples from across the Philippines, the land is frequently taken without obtaining FPIC, and indigenous peoples are suffering negative impact on their ways of life, health and environment. The mining operations have often negative impacts on social infrastructure (Moffat \& Zhang, 2013).

The Philippine governments in their attempts to woo foreign direct investment appeared willing to circumvent the country`s laws protecting the environment and human rights and reduce standards below acceptable international practice according to the report of a fact finding team visiting three mining-affected communities in Mindanao (Doyle et al., 2007). While the laws require FPIC of the affected communities, the evidence suggests that the responsible government agencies have failed to effectively apply the law due to limited resources, both in terms of budget and expertise required to deal with complex matters of consent in indigenous communities (Christian Aid, 2004; Franco, 2014; Doyle \& Carino, 2013; Collins, 2016). The consent is sometimes obtained through misinformation, misrepresentation, bribery and intimidation; several incidents where companies violated the legal guidelines and engineered the required consent were reported for instance by Doyle et al. (2007).

The literature is divided regarding the impact of mining on poverty levels. Though Loayza and Rigolini (2016) recorded lower poverty levels in mining districts of Peru, they found the inequality there larger than in non-mining districts. Boquiren (2008) has shown that poverty is in fact worse in mining than in non-mining areas of the Philippines. Moreover, roads built by the logging companies make indigenous areas accessible to domestic outsiders who immigrate in large numbers with negative social, economic and environmental consequences (Foster, 2012). While companies express their commitment to high environmental standards and good relations with their host communities, the communities themselves tell of the repeated violations of the environmental standards and human rights by companies and their employees (Christian Aid, 2004; Thomson \& Joyce, 1997; OECD, 2002). Examples of responsible mining in the Philippines barely exist with a few exceptions such as Coral Bay in Palawan or Philex's operation in Benguet (Foundation for Environmental Security and Sustainability, 2007).

\section{Research Methodology}

In order to illustrate the implementation gap between the rights of indigenous peoples in law and practice in the Philippines, social impact of agribusiness and mining industry on indigenous peoples' communities and roles played by different stakeholders, the paper employs qualitative descriptive case study design. This has enabled 
exploration and deeper analysis of community-level factors affecting the process of securing land tenure and negotiation with private companies and government bodies.

\subsection{Data collection and analysis}

Because of the qualitative rather than quantitative nature of the research, the primary methodological approach to the field data collection were 8 focus group discussions and 20 in-depth interviews. Data were analysed using content analysis where recurring themes were identified and coded to reflect the emerging patterns, which were interpreted later by the authors employing phenomenological approach using abductive reasoning.

The primary data were collected in April and July 2016 with additional data collection in February 2017 combining several methods -6 focus group discussions with tribal council and barangay representatives, 2 focus group discussions with staff of local NGOs working with indigenous peoples in Northern Mindanao, 6 in-depth interviews with tribal leaders, 6 in-depth interviews with local NGO workers, 8 key informant interviews with representatives of provincial NCIP, national and provincial Commission for Human Rights (CHR) and provincial office of Department of Agrarian Reform (DAR) as well as dozens of informal discussions with members of Higaonon tribe. The semi-structured discussion among focus group discussion participants provided an opportunity to hear issues that may have not emerged from participants' individual interaction with researchers. Moreover, their interaction led to increased emphasis on the participants' perspectives rather than ours and permitted discovery of aspects of understanding that would have otherwise remained hidden in the more conventional in-depth interviewing method. We supplemented the interviews and focus group discussions with field observations and the collection of relevant publicly available documents.

The paper also relies on dozens of semi-structured interviews with key Philippine and expatriate NGO workers and Philippine government representatives that were conducted by the first author between November 2013 and February 2017 and that helped to inform our understanding of indigenous peoples' rights, mining, agribusiness and land issues and their dynamics in the Philippines. In this regard, it is important to mention the huge ideological divisions of the Philippine civil society. Borras and Franco (2007) classify the organizations into four categories - groups identified with the revolutionary Communist left, state-coopted organizations, conservative reformists and progressive left reformists. While the first category was largely behind the campaign against the land grabbing in Opol, it was the representatives of the other groups, and mainly the latter two, that were informants for our research.

We see the main limitation of this paper in the fact that it is relying too much on local testimony and description of the ex-ante situation based largely on the information reported by the indigenous people and NGOs. As such, it could contain several potential sources of bias. Repeated attempts to conduct semi-structured interviews with representatives of the companies failed and we thus had to rely only on publicly available information such as companies' web pages and social media sites, their annual reports as well as papers published by NGOs and activists who were engaged in Opol case mainly in 2011-13. Unlike in 2016, the authors could not visit the ancestral domain in February 2017 because of presence of the New People's Army in the area and all the focus group discussions and interviews had to be conducted outside of the ancestral domain in Poblacion and Cagayan de Oro.

\subsection{Site description}

Opol is a municipality in Misamis Oriental province covering an area of 17513 hectares. Its boundary lies some 11 kilometres west of Cagayan de Oro, one of the major cities in Mindanao. According to official 2015 census, Opol municipality had population of 61503 (Philippine Statistics Authority, 2017). Opol consists of 14 barangays or villages. In six of these - Awang, Bagocboc, Tingalan, Nangcaon, Caoyonan and Limonda - as well as in two barangays of neighbouring Mantiaco municipality - Mahayahay and Upper Malobog - Higaonon people form majority population with approximately 11000 individuals. All these barangays have barangay tribal councils, a parallel local governance structure for indigenous people. Ancestors of these Higaonon people have resided in Opol and Mantiaco since pre-colonial times. The name Higaonon means 'people of the mountains'. Higaonon are one of the 18 ethnic groups of Lumads, a generic term embracing all non-Muslim hill tribes of Mindanao, which means 'native, indigenous, local, grown to a place' in Cebuano/Visaya language. Lumads form the largest grouping of indigenous peoples in the country with a total population of 2.1 million.

The site of this study was selected because several issues of interest for this research are present here. Firstly, the indigenous community has been seeking Certificate of Ancestral Domain Title (CADT) to secure rights over land and natural resources already since 2001. Secondly, the area has been targeted by A. Brown Company, Inc., and its subsidiaries Nakeen Corporation and ABERDI (further referred to collectively as 'A. Brown'), for oil palm plantation in 2011. Although often referred to as an American owned company, the company is in fact $100 \%$ 
Filipino owned. Thirdly, two mining exploration concessions were awarded in the area. In 2011, Black Stone Mineral Resources Inc., a subsidiary of Hong Kong based company, received concession for exploration of gold and associated minerals and Filipinas (Prefab Bldg.) Systems Inc. obtained exploration concession for chromite (PMCDC, 2015).

\section{Results and Discussion}

\subsection{Application for Certificate of Ancestral Domain}

The first claim for CADT in Opol was made in 2001 for only one of the eight Higanon-majority barangays. According to a focus group discussion with tribal leaders and interviews with NGO workers, after the pressure from NCIP, a large, joint claim for all Higaonon-majority barangays was developed in 2006 rather than applying for separate CADTs in each barangay. According to Prill-Brett (2007), this is a widespread practice that may appear to be efficient in simplifying the application process, however, it might not match with a traditional mechanism for managing such supra-community domain and might not be an effective strategy to foster sustainable resource management, community equity and social justice. As shown also by this case study, the application process is not made quicker by this - Higaonon people of Dulangan have not obtained CADT until today. They are currently in the latest stages of the process of drafting Ancestral Domain Sustainable Development and Protection Plan that is one of the pre-conditions for issuance of CADT. According to the focus group discussion with tribal leaders and interview with an NCIP representative, the planning process should finish in March 2017 by presentation of the draft plan to the indigenous community, its validation and approval.

During the focus group discussions, tribal leaders expressed their hope that the land survey by NCIP will happen soon so that the boundary of the ancestral domain could be finally set after years of waiting. However, the NGO informants were convinced during the July 2016 discussion that this would not happen any time soon: "unless the President fulfils his election campaign promise of allocating additional resources to NCIP to be capable of fast-tracking the processing and approval of applications for CADTs. NCIP does not have sufficient capacities and resources to conduct land surveys of these large areas claimed." In February 2017, the NCIP informant claimed that the plan is to conduct the land survey, delineation and award CADT for Dulangan within next six months: "We are under the pressure from the President to speed up the CADT cases and while Congress has not approved increase in budget allocation to NCIP, we have received funds for the land surveys from other budget lines of the Office of the President." Municipal administration has pledged funds for delineation, too, according to him and NGO informants. Tribal focus group discussion participants had no knowledge of any of these.

One of the factors causing the delays in CADT process mentioned by all tribal, NGO and NCIP informants was Joint Administrative Order 1-2012 of NCIP, DAR, Department of Environment and Natural Resources (DENR), and Land Registration Authority, which suspended all titling activities in identified contentious areas and created a joint committee mechanism to resolve the issues (GoP, 2012). NGO informants were critical about how functional and effective this mechanism is and NCIP representative told us: "These are very tough meetings when they happen. However, because we had no funding to hold them, they had become discontinued and that is why some of the CADT applications stalled. Fortunately, this year we were allocated budget at least for food at these meetings so we should revive them." In this connection, it would be interesting to mention the opinion of the interviewed DAR representatives: "Almost all Mindanao is claimed by NCIP and by indigenous peoples as their ancestral domains. We have to issue our land titles within the ancestral domains if we are to implement the agrarian reform at all."

According the NGO informants, another factor delaying the CADT processing is historically poor relationship between Dulangan chief datu and Mayor of Opol municipality which also means that Opol has no mandatory indigenous representative in the municipal council: "While the Mayor will never let him sit on the council, datu will not let anyone else from the tribe to take over this role." Tribal focus group discussion participants were also speaking about a conflict between them and NCIP in the past: "We used to have arguments with them; they even refused to recognize our tribal council and wanted to establish another one by themselves. But now NCIP understands their function and role and our relation has significantly improved."

One of the tribal focus group discussion participants said: "Since 2006 many NGOs were coming and going. They were asking about the issues, but then their projects ended and nothing has happened. Efforts of NGOs are not recognized by NCIP and there is a problematic relationship between NGOs and NCIP." In contradiction to this, our NCIP informant cited concrete examples of collaboration with NGOs for example on land surveying or delineation of ancestral domains. The tribal focus group discussion participants agreed among themselves that they would want from a specific NGO supporting their cause to play more pro-active role in solving the problems of Dulangan ancestral domain: "The NGO and NCIP should sit together and review what has been 
done and what the next steps should be." However, the NGO informants and focus group discussion participants were convinced that their role is "to provide necessary skills to indigenous peoples and they have to fight for their CADT themselves. We can't do it for them, since they would have no ownership then." In this connection it would be interested to refer to McDermott (2000) who is sceptical about motivation of some of the Philippine NGOs, according to him the focus on indigenous peoples "is currently the raison d'être for a number of NGOs and serves them as an effective strategy for raising foreign interest and funds."

\subsection{Activists' land grabbing narrative versus tribal leaders'one}

In the narrative based on the International Fact Finding Mission and disseminated by the activist NGOs' campaigns (for example Quijano, 2012; KALUMBAY et al., 2011; Asia Monitor Resource Center, 2013), we are told that A. Brown has grabbed the land from a group of indigenous farmers who formed Sarahogon Bagocboc Farmers Association (SBFA). They resettled and farmed the land taken earlier from the tribe and granted as Forest Land Grazing Lease Agreement by DENR to a private company that later abandoned it. In 2002, this same land was, following years of petitions to regain the indigenous lands, granted to DENR-facilitated formation Kahugpongan sa Mag-uuma sa Barangay Tingalan (KMBT) instead to SBFA under a Community-based Forest Management Agreement. In February 2011, A. Brown in preparation for oil palm plantation operations organized community meeting with handpicked community members while community leaders were not invited and given a voice (Quijano, 2012). These handpicked members were from KMBT and signed Memorandum of Agreement with A. Brown after being told that though A. Brown possessed the land now, farmers would not be displaced if they chose not to sign their lands over to A. Brown and would be compensated if they chose to leave (Quijano, 2012). In direct violation of the A. Brown-KMBT Memorandum of Agreement and without FPIC with the wider community - some Higaonon families found out that their farmland was included in A. Brown plantation only when the area was marked off by sticks on the ground by A. Brown personnel -, A. Brown began constructing an access road and planting palms in local farmers' fields and ancestral sites (KALUMBAY et al., 2011). A sacred hilltop, which served as the burial ground of the ancestors, was quarried by the company for road construction (Quijano, 2012). The company also planted oil palm in a ritual area called Bagonsilibo, an act considered as desecration by tribal elders. A tree marking the burial ground and ritual area was cut down by A. Brown personnel (KALUMBAY et al., 2011).

However, during the focus group discussions the authors held with tribal leaders, a contradicting picture has emerged: "The International Fact Finding Mission avoided any contact with the tribal council so they had hardly all the information. As a result we did not attend any of their advocacy events or the congressional hearing." According to datus, SBFA farmers had encroached the land and it was KMBT legally in charge of the land. KMBT had thus the backing of the tribal council and the people negotiating with A. Brown could hardly be called 'handpicked'. They stressed that they managed to negotiate in the Memorandum of Agreement with A. Brown that $70 \%$ of the plantation workers would be local Higaonons. The destroyed ritual area of Bagonsilibo is a Higaonon sacred place but it is actually in neighbouring ancestral domain in Cagayan de Oro municipality not in Dulangan and has nothing to do with A. Brown oil palm plantation according to focus group discussion participants. "It depends on your Memorandum of Agreement with the company. In our case destroying of ritual areas would not be possible; things like this are under our control," datus agreed during the discussion.

\subsection{Social cohesion and community disagreements}

NGOs in their campaign (for example Asia Monitor Resource Center, 2013; KALUMBAY et al., 2011; Quijano, 2012) documented incidents of harassment, intimidation and violence, including destruction of crops, burning of houses and death threats, commenced immediately after A. Brown started operations. The worst incident was 2012 killing of Gilbert Paborada, leader of resistance against A. Brown, and of Rolen Langala, his successor, a year later. The cases have remained unresolved but Paborada's family and some Higaonon residents claimed that the killing of Paborada was directly related to his work as a leader of the 'resistance movement' against A. Brown oil palm expansion in Opol. Interviewed CHR representative told us that there is "enough circumstance to lead to conclusion that Gilbert Paborada's death was connected with his struggle against A. Brown. However, CHR is not doing 'police work', so we cannot prove it. The investigation resolution was submitted to the House of Representatives." Interestingly CHR 2012 report is not that conclusive citing barangay treasurer and at the same time KMBT board member who "does not believe A. Brown has something to do with the killing of Gilbert as the victim's uncle and the former barangay captain are employees of A. Brown" (CHR, 2013). Tribal leaders said during the focus group discussion in regard to Paborada's killing: "He was not fighting for the cause of the whole tribe but only his group of farmers SBFA. He established his own organization Pangalasag [to represent the tribal interests against A. Brown] despite strong opposition of the tribal council against it." When we asked NGO informants why Paborada's death was not mentioned during the focus group discussions and 
in-depth interviews held in July 2016, they explained that there are more than 70 plus clans living in Dulungan and that their relations are sometime quite tense and referred to complicated 'tribal dynamics'.

It was observed by the authors and confirmed with the informants that a number of families in Tingalan and Bagocboc barangays started small-scale oil palm farming selling their produce to A. Brown. At the same time, according to focus group discussions with community leaders and in-depth interviews with NGO staff, some of the household leased their land to the company for the period of 25 years for a mere 9,000 pesos (approximately 180 USD). Tribal leaders claimed that the total land area leased directly by individuals and families to A. Brown for oil palm plantation was 325 hectares.

During the in-depth interviews, companies' divide-and-rule tactics weakening social cohesion among the Higaonon was mentioned several times. This tactics supposedly includes the co-optation of some indigenous leaders through bribery, both direct (money offers) and indirect (promises of jobs, social services, and over-all prosperity): "Those who disagree with the companies get co-opted by high paid jobs or by being promoted." The authors observed that captains in two barangays were able to build new above-standard houses.

According the in-depth interviews, mining company Blackstone initiated community meeting for FPIC only after the exploration concession had been granted by the Philippine Mining Development Corporation and DENR. While initially barangay tribal council was against the exploration, barangay council agreed. "We wanted to avoid community friction so after facilitation between the two councils, tribal council gave its approval at the end," explained datus during the focus group discussion. The reasons behind disagreement between the tribal barangay council on the one hand and barangay officials and some community members on the other hand over consent with mining exploration in Nangcaon was explained by focus group discussion: "The company offered minimum daily wage of 300 pesos (approximately 6 USD) which was simply irresistible for some of our people."

The mining company Filipinas Systems held reportedly two community assemblies in Awang barangay as part of the FPIC process for exploration and the next step is drafting of Memorandum of Agreement between Filipinas Systems and the tribal council of Awang barangay (PMDC, 2015). Tribal focus group discussion participants informed us in February 2017 that "last week there was another community meeting in Awang to secure FPIC. The problem is they never tell people in advance the reason of the meeting or that this is actually an FPIC."

\subsection{Future plans with ancestral domain}

The indigenous culture, customs and traditions in Dulangan are dying out as observed in the field and confirmed by focus group discussions and in-depth interviews with the tribal leaders. One of the NGO informants even claimed during an informal discussion that some of the "indigenous peoples [in Mindanao] do not observe traditions and customs anymore. Often they would organize themselves as indigenous group and re-discover their culture and traditions simply to secure land because the government believes that all indigenous communities are entitled to ancestral domain."

In July 2016 it seemed like the Higaonon's ultimate goal in Dulangan was to obtain the CADT and that they did not give much thought how they would approach A. Brown and Blackstone after they have secured recognition of their ancestral domain rights. "We do not know what we would demand from the companies once our claim is granted," was repeated several times during the focus group discussion as well as informal and in-depth interviews. The situation was quite different in February 2017. After the indigenous community undertook several steps of the Ancestral Domain Sustainable Development and Protection planning, their plan was to leave $40 \%$ of the land as protected area without any farming, hunting or mining. In the remaining areas, focus group discussion participants talked about artisanal, small-scale mining among other livelihoods activities. "We have established five cooperatives which will extract gold and nickel in a traditional way." In order to do this, they have even started collaboration with a Chinese mining company. While some focus group discussion participants raised concerns about possible environmental impact of mining, others pointed to the fact that mining was practiced traditionally by the indigenous people here in the past and that dulangan actually means 'mine'.

During the focus group discussions, participants from more remote barangays mentioned they do not want to develop the area for intensive agriculture. Rather they want to keep it for their traditional livelihoods: "We cut trees only when timber is needed for construction because they are sacred to us. We want to continue with swidden farming of food crops as well as abaca - Manila hemp - and raising of ducks and chicken, hunting of wild pigs and birds and fishing in rivers and creeks. We also want to continue harvesting non-timber forest products such as rattan, bagacay [of the Bambuseae tribe], wild food and medicinal plants." At the same time we observed, that discussion participants from barangays closer to the main road, where they are engaged in 'modern' farming, were less bound by traditional livelihoods: "We want to farm rice, corn, cassava, bananas and 
coconut... in a way integrating modern and traditional farming. In this regard we might need some external assistance in switching from chemical pesticides and fertilizers that we use now to organic ones."

During the focus group discussions and in-depth interviews, all Higaonons claimed to hold no particular grudge against the non-indigenous settlers who currently reside in their villages. They would allow them to stay after receiving the CADT. They would however more strongly insist that the settlers respect indigenous customs and traditions. Admission of new settlers will supposedly be decision made by each barangay separately. One tribal leader reported: "In Nangcaon we won't allow any new settlers because we can see that settlers just create additional problems for us. And I believe this will be probably the case for all barangays with currently low numbers of settlers."

There has been an interesting development regarding the mining companies and agribusiness in Opol recently. A. Brown has temporary suspended their operations in Opol in August 2016 for 6 months without informing the tribal leaders. 143 people, out of which 100 were local Higaonon, have lost their jobs as a result. Tribal focus group discussion participants said in February 2017 that they "had a meeting with A. Brown last week. A. Brown has no plans to restart operations in Opol and will return all the land to KMBT and tribe under the condition that we must sell our [oil palm] bunches only to A. Brown. We will meet again to tell them we want to cancel Memorandum of Agreement because they are not fulfilling it. The question is what will happen to people who leased them their land. A. Brown wants them to pay back for the oil palms planted."

According to focus group discussion with tribal leaders, Blackstone exploration concession ran until February: "but they had already stopped before. Now they only have one person guarding there." It is important to note in this connection that mining industry experience suggests that only less than $10 \%$ advanced exploration programs actually turn into full-scale mining operations (Thomson \& Joyce, 1997).

\section{Conclusion}

This paper has sought to clarify the difficult situation faced by indigenous communities in the Philippines when confronted by State-backed efforts to promote agribusiness and mining in their ancestral lands and domains. Although the paper focuses on the Northern Mindanao experience, some of the problems and issues presented here may well apply to other indigenous areas in the Philippines and even elsewhere. We have shown the significance of land and its complexities to the indigenous peoples and problems in implementation of IPRA, specifically in issuance of CADT. Differences in visions, mandates and instruments of various government bodies contribute to delays in CADT issuance, as well as lack of resources to conduct land surveys, delineations or hold coordination meetings between the various government bodies.

As the testimonies collected in this case study have shown, indigenous people have given their FPIC to mining exploration in order to avoid frictions within the community regardless of what they considered as best for their community. While no doubt some community members can benefit from the mining and plantation operations, others who attempt to maintain their traditional ways of life suffer and fear what would happen if the operations moved from exploration to extraction phase. The main problem in strengthening community land tenure seems to be disunity among the indigenous peoples, conflicting personal interests among tribal members and leaders bringing about tensions in social and personal relationships of several indigenous peoples' leaders. This is contradicting the black-and-white picture, which some activist NGOs portray in their land grabbing narratives. We have also shown how companies are using divide-and-rule tactics and co-optation of some tribal members to enhance their business interests.

We have shown that conflicts over decision-making on resource allocation lead to further weakening of tribal social cohesion. However, additional in-depth research of intra-tribal relations and dynamics would be needed to better understand the complexities of indigenous decision-making on land and natural resources related issues. We were not able to determine legitimacy of the tribal leaders dealing with external stakeholders across the clans, generations and socio-economic strata.

We conclude here that the mere existence of communal ancestral domain tenurial instruments does not automatically lead to sustainable environmental management or to social justice.

\section{Acknowledgments}

This research was supported by the Internal Grant Agency project [20175012] at the Faculty of Tropical AgriSciences, Czech University of Life Sciences, Prague.

\section{References}

AFRIM. (2011). Land Conversion and Agrofuel Plantations in Mindanao: Promises and Uncertainties. 
Kasarinlan: Philippine Journal of Third World Studies 26(1-2), 285-294.

Arquiza, Y. D. (Ed.). (2005). Journey of Hope: Implementing the Indigenous Peoples Rights Act of the Philippines. Volume 3: The Road to Self-governance. Manila: International Labour Office (ILO).

Asia Monitor Resource Center (AMRC). (2013). Organizing Strategy Case Study of Palm Oil Plantation in Mindanao, Philippines. Retrieved from http://www.amrc.org.hk/sites/default/files/ Case \%20Study\%20of\%20Organizing\%20Strategy-Mindanao.pdf

Bolton, N. \& Leguro, M. (2015). Local Solutions to Land Conflict in Mindanao. Catholic Relief Services (CRS). Retrieved from http://www.crs.org/sites/default/files/tools-research/local-solutions-to-land-conflict-in-mindanao.pdf

Boquiren, A. C. (2008). Validating policy prescription from benefit-cost assessment of mining through comparative analysis and test of hypothesis. Philippine Review of Economics 45(1), 57-68.

Borras, Jr. S. M. \& Franco, J. (2007). The National Campaign for Land Reform in the Philippines. Brighton: University of Sussex, Institute for Development Studies. Retrieved from http://www.ids.ac.uk/ids/Part/proj/pnp.html

Borras, Jr. S.M. \& Franco, J. (2011). Political Dynamics of Land-grabbing in Southeast Asia: Understanding Europe's Role. Amsterdam: Transnational Institute.

Calde, N.L., Ciencia, A.N. Jr. \& Rovillos, R.D. (2013). An assessment of the implementation of the Free and Prior Informed Consent (FPIC) in the Philippines. Volume I: Main Report. Manila: Deutsche Gesellschaft für Internationale Zusammenarbeit (GIZ) GmbH.

Carino, J. (2009). Poverty and Well-being. Chapter 1. In United Nations, State of the World's Indigenous People (pp. 14-49). New York: United Nations. Department of Social and Economic Affairs. Division for Social Policy and Development. Secretariat of the Permanent Forum on Indigenous Issues.

Carino J. (2012). Country Technical Note on Indigenous Peoples' Issues. Republic of the Philippines. Rome: IFAD.

Carlson, K.M., Curran, L.M., Ratnasari, D., Pittman, A.M., Soares-Filho, B.S., Asner, G.P., Trigg, S.N., Gaveau, D.A., Lawrence, D. \& Rodrigues, H.O. (2012). Committed carbon emissions, deforestation, and community land conversion from oil palm plantation expansion in West Kalimantan, Indonesia. Proceedings of the National Academy of Sciences 109, 7559-7564. http://dx.doi.org/10.1073/pnas.1200452109

Christian Aid. (2004). Breaking promises, making profits: Mining in the Philippines. Retrieved from www.piplinks.org/development_issues/philippines_report.pdf

Collins, N. (2016). Lessons from Implementing Free Prior and Informed Consent (FPIC) in the Philippines: A Case Study for Teaching Purposes - Facilitator's Guide. Queensland: Centre for Social Responsibility in Mining. Sustainable Minerals Institute. The University of Queensland, Australia.

Commission on Human Rights of the Philippines (2013). 2012 Annual Report. Annual Accomplishment Report of the Commission on Human Rights of the Philippines. Retrieved from http://www.chr.gov.ph /MAIN\%20PAGES/about\%20us/PDF/2012_chr_annual_report.pdf

Crisologo-Mendoza, L. \& Prill-Brett, J. (2009). Communal Land Management in the Cordillera Region of the Philippines. In Perera J. (Ed.), Land and cultural survival: the communal land rights of indigenous peoples in Asia (pp. 35-61). Mandaluyong City, Philippines: Asian Development Bank.

Dove, M.R. (2006). Indigenous People and Environmental Politics. Annual Review of Anthropology 35, 191-208. http://dx.doi.org/ 10.1146/annurev.anthro.35.081705.123235

Doyle, C. \& Carino, J. (2013). Making Free Prior \& Informed Consent a Reality. Indigenous Peoples and the Extractive Sector. Retrieved from http://www.ecojesuit.com/wp-content/uploads/2014/09/Making-FPIC-a-Reality-Report.pdf

Doyle, C., Wicks, C. \& Nally, F. (2007). Mining in the Philippines. Concerns and conflicts. Report of a Fact-Finding Trip to the Philippines. Solihull, UK: Society of St. Columban.

Environmental Investigation Agency. (2015). Oil palm plantations in Colombia expand into indigenous territory: Native cultures' Sikuani and Jiw sacred sites and livelihoods at risk. Retrieved from https://intercontinentalcry.org/oil-palm-plantations-in-colombia-expand-into-indigenous-territory/

Erasga, D. (2008). Ancestral Domain Claim: The Case of the Indigenous People in Muslim Mindanao (ARMM). 
Asia-Pacific Social Science Review 8(1), 33-44. https://doi.org/10.3860/apssr.v8i1.704

Foster, G.K. (2012). Foreign Investment and Indigenous Peoples: Options for Promoting Equilibrium between Economic Development and Indigenous Rights. Michigan Journal of International Law 33(4). Retrieved from http://repository.law.umich.edu/mjil/vol33/iss4/1

Foundation for Environmental Security and Sustainability. (2007). A Double-Edged Sword? Implications of Mining for Environmental Security in the Philippines. Retrieved from http://www.fess-global.org/Publications/Other/philippines_esaf_report.pdf

Franco, J. (2014). Reclaiming Free Prior and Informed Consent (FPIC) in the context of global land grabs. Amsterdam: Transnational Institute.

Friends of Earth. (2008). Losing Ground. The human impacts of palm oil expansion. Retrieved from https://www.foe.co.uk/sites/default/files/downloads/palmed_off.pdf

Global Witness. (2016). Palm oil giant Golden Veroleum bulldozes religious sites in Liberia, protected by armed police. Retrieved

from https://www.globalwitness.org/en/press-releases/palm-oil-giant-golden-veroleum-liberia/

Göcke, K. (2013). Protection and Realization of Indigenous Peoples' Land Rights at the National and International Level. Goettingen Journal of International Law 5, 87-154. http://dx.doi.org/10.3249/1868-1581-5-1-goecke

Goodland, R. \& Wicks, C. (2008). Philippines: Mining or Food? London: Working Group on Mining in the Philippines.

Government of the Philippines (GoP). (1975). Official Gazette. Presidential Decree No. 705, s. 1975. Revising Presidential Decree No. 389 Otherwise Known as the Forestry Reform Code of the Philippines. Manila: Government of the Philippines. from http://www.gov.ph/1975/05/19/presidential-decree-no-705-s-1975/

Government of the Philippines (GoP). (1997). Official Gazette. Republic Act No. 8371. Manila: Government of the Philippines. Retrieved from http://www.gov.ph/1997/10/29/republic-act-no-8371/

Government of the Philippines. Joint DAR-DENR-LRA-NCIP Administrative Order No. 01 Series of 12. Retrieved from http://ncipr1.com/wp-content/uploads/2014/11/joint-dar-denr-lra-ncip-administrative-order-no-01-series-of2012-.pdf

Government of the Philippines (GoP). (2015). 'Just economy' and inclusive growth in an autonomous Bangsamoro. DevPulse 18. Pacig City: National Economic and Development Authority, Republic of the Philippines.

Hall, D. (2011, April). Land Control, Land Grabs, and Southeast Asian Crop Booms. Paper presented at the International Conference on Global Land Grabbing, Sussex. http://dx.doi.org/10.1080/03066150.2011. 607706

Hilson, G. (2002). An overview of land use conflicts in mining communities. Land Use Policy 19(1), 65-73. http://dx.doi.org/10.1016/S0264-8377(01)00043-6

Inman, D. (2016). From the Global to the Local: The Development of Indigenous Peoples' Land Rights Internationally and in Southeast Asia. Asian Journal of International Law 6(1), 46-88. https://doi.org/10.1017/S2044251314000356

IOM [International Organization for Migration] \& World Bank. (2013). Land Disputes in Conflict Affected Areas of Mindanao: Report of the Joint World Bank - International Organization for Migration Scoping Mission. Retrieved from https://www.iom.int/files/live/sites/iom/files/What-We-Do/docs/Land-Disputes-in-Conflict-Affected-Areasof-Mindanao.pdf

KALUMBAY Regional Lumad Organization, Kilusang Magbubukid ng Pilipinas Northern Mindanao Region, Rural Missionaries of the Philippines. (2011). An initial paper on the Nakeen Corp./ABERDI Oil Palm Plantation in Opol, Misamis Oriental, Philippines. Retrieved from http://library.ipamglobal.org/jspui/bitstream/ipamlibrary/522/1/OPOL_Oil_Palm_Primer.pdf

Lee, J.S.H., Abood, S., Ghazoul, J., Barus, B., Obidzinski, K. \& Koh, K.P. (2014). Environmental impacts of large-scale oil palm enterprises exceed that of smallholdings in Indonesia. Conservation Letters 7(1), 25-33. 
http://dx.doi.org/10.1111/conl.12039

Llanto, G.M. \& Ballesteros, M.M. (2003). Land Issues in Poverty Reduction Strategies and the Development Agenda: Philippines. Makati City, Philippines: Philippine Institute for Development Studies.

Loayza, N. \& Rigolini, J. (2016). The Local Impact of Mining on Poverty and Inequality: Evidence from the Commodity Boom in Peru. World Development 84, 219-234. http://dx.doi.org/10.1016/j.worlddev. 2016.03.005

Lynch, O.J. (2005). Concepts and Strategies for Promoting Legal Recognition of Community-Based Property Rights: Insights from the Philippines and Other Nations. In Brosius, J.P., Lowenhaupt Tsing, A. \& Zerner, C., Communities and Conservation. Histories and Politics of Community-Based Natural Resource Management (pp. 391-426). Walnut Creek, CA: Altamira Press.

Maher, D. (2014). Rooted in violence: Civil war, international trade and the expansion of palm oil in Colombia. New Political Economy 20(2), 299-330. http://dx.doi.org/10.1080/13563467.2014.923825

McDermott, M.H. (2000). Boundaries and Pathways: Indigenous Identities, Ancestral Domain, and Forest Use in Palawan, the Philippines. Retrieved from https://www.researchgate.net/publication/42761543 Boundaries_and_Pathways_Indigenous_Communities_Ancestral_Domain_and_Forest_Use_in_Palawan_t he_Philippines

Melanes, M. (2002). Power from the Mountains. Indigenous Knowledge Systems and Practices in Ancestral Domain Management: The Experience of the Kankanaey-Bago People in Bakun, Benguet Province, Philippines. Baguio City, Philippines: International Labour Organization.

Moffat, K. \& Zhang, A. (2014). The paths to social licence to operate: An integrative model explaining community acceptance of mining. Resources Policy 39, 61-70. http://dx.doi.org/10.1016/j.resourpol.2013.11.003

Molintas, J.S. (2004). The Philippine Indigenous Peoples' Struggle for Land and Life: Challenging Legal Texts. Arizona Journal of International \& Comparative Law 21(1), 269-306.

Novellino, D. (2000). Recognition of Ancestral Domain Claims on Palawan Island, the Philippines: is there a Future? Retrieved from ftp://ftp.fao.org/sd/sda/sdaa/LR00/05-Land.pdf

Obidzinski, K., Andriani, R., Komarudin, H. \& Andrianto, A. (2012). Environmental and social impacts of oil palm plantations and their implications for biofuel production in Indonesia. Ecology and Society 17, http://dx.doi.org/10.5751/ES-04775-170125

OECD. (2002). Foreign Direct Investment and the Environment. Lessons from the Mining Sector. Paris: Organisation for Economic Cooperation and Development (OECD) Global Forum on International Investment.

O'Faircheallaigh, C. (2012). International Recognition of Indigenous Rights, Indigenous Control of Development and Domestic Political Mobilisation. Australian Journal of Political Science 47, 531-545. http://dx.doi.org/ 10.1080/10361146.2012.731484

O'Faircheallaigh, C. (2013). Extractive industries and Indigenous peoples: A changing dynamic? Journal of Rural Studies 30, 20-30. http://dx.doi.org/10.1016/j.jrurstud.2012.11.003

Owen, J.R. \& Kemp, D. (2014). 'Free prior and informed consent', social complexity and the mining industry: Establishing a knowledge base. Resources Policy 41, 91-100. http://dx.doi.org/10.1016/ j.resourpol.2014.03.006

Owen, J.R. \& Kemp, D. (2015). Mining-induced displacement and resettlement: a critical appraisal. Journal of Cleaner Production 87, 478-488. http://dx.doi.org/10.1016/j.jclepro.2014.09.087

Perera, J. (Ed.). (2009). Land and cultural survival: the communal land rights of indigenous peoples in Asia. Mandaluyong City, Philippines: Asian Development Bank.

Philippine Statistics Authority. (2017). 2015 Census of Population. Retrieved from https://psa.gov.ph/statistics/ census/2015-census-of-population

PMDC (Philippine Mining Development Corporation). (2015). PMDC Projects as of September 2015. Retrieved from http://pmdc.com.ph/documents\%202013/projectstat2015.pdf

Potter, L. (2012). Dayak Resistance to Oil Palm Plantation in West Kalimantan, Indonesia. Retrieved from http://artsonline.monash.edu.au/mai/files/2012/07/lesleypotter.pdf 
Prachvuthy, M. (2011). Land Acquisition by Non-Local Actors and Consequences for Local Development: Impacts of Economic Land Concessions on the Livelihoods of Indigenous Communities in Northeast Provinces of Cambodia. Phnom Penh: Royal University of Phnom Penh, Faculty of Humanities and Social Science.

Prill-Brett, J. (2007). Contested Domains: The Indigenous Peoples Rights Act (IPRA) and Legal Pluralism in the Northern Philippines. Revised version of paper presented at the 7th International Philippine Studies Conference, Leiden, The Netherlands. Retrieved from http://commission-on-legal-pluralism.com/volumes/55/prillbrett-art.pdf

Quijano, I.I.D. (2012). The Real Trespassers: Landgrabbing in the Name of Palm Oil in Southern Philippines. Speak Out! Pesticide Action Network, Asia and the Pacific (PAN AP). Retrieved from http://www.panap.net/sites/default/files/SO-2012June-TheRealTrespassers.pdf

Rey, T. (2010). Indigenous Peoples in the Philippines: Continuing Struggle. Focus Asia-Pacific 62, 6-9.

Sandker, M., Suwarno, A., Campbell, B.M. (2007). Will forests remain in the face of oil palm expansion? Simulating change in Malinau, Indonesia. Ecology and Society 12(2): 37. https://doi.org/10.5751/ES-02292-120237

Schneider, A. E. (2011, April). What shall we do without our land? Land Grabs and Resistance in Rural Cambodia. Paper presented at International Conference on Global Land Grabbing, Sussex.

Schoneveld, G.C., German, L.A. \& Nukator, E. (2011). Land-based investments for rural development? A grounded analysis of the local impacts of biofuel feedstock plantations in Ghana. Ecology and Society 16(4). https://doi.org/10.5751/ES-04424-160410

Scoones, I., Hall, R., Borras, Jr. S.M., White, B. \& Wolford, W. (2013). The politics of evidence: methodologies for understanding the global land rush. The Journal of Peasant Studies 40(3), 469-483. http://dx.doi.org/10.1080/03066150.2013.801341

Selvadurai, S., Er., A.C., Lyndon, N., Sum, S.M., Saad, S., Manaf, A.A. \& Ramli, Z. (2013). Penan Natives' Discourse for and against Development. Asian Social Science 9(8). http://dx.doi.org/10.5539/ass.v9n8p72

Simbolon, I. (2009). Law Reforms and Recognition of Indigenous Peoples' Communal Rights in Cambodia. In Perera J. (Ed.). Land and cultural survival: the communal land rights of indigenous peoples in Asia (pp. 63-91). Mandaluyong City, Philippines: Asian Development Bank.

Sokhannaro, H.E.P. (2011). Palm Oil Development in Cambodia. In Colchester, M. \& Chao, S. Oil Palm Expansion in South East Asia: trends and implications for local communities and indigenous peoples (pp. 64-91). Moreton-in-Marsh: Forest Peoples Programme and Bogor - West Java: Perkumpulan Sawit Watch.

Survival International. (2011). Palm oil expansion threatens Palawan tribe. Retrieved from http://www.survivalinternational.org/news/6876

Tauli-Corpuz, V. \& Tamang, P. (2007). Oil Palm and Other Commercial Tree Plantations, Monocropping: Impacts on Indigenous Peoples' Land Tenure and Resource Management Systems and Livelihoods. New York: UNPFII [United Nations Permanent Forum on Indigenous Issues]

Thomson, I. \& Joyce, S. (1997, May). Mineral Exploration and the Challenge of Community Relations. Paper presented at conference Mining and the Community, Quito, Ecuador.

Tujan, Jr. A. (2002). Corporate Imperialism in the Philippines. In Evans, G., Goodman, J. \& Lansbury, N. Moving Mountains: Communities Confront Mining and Globalisation (pp. 147-164). London, New York: Zed Books.

United Nations (UN). (2003). Report of the Special Rapporteur on the situation of human rights and fundamental freedoms of indigenous people. Geneva: United Nations Commission on Human Rights, Economic and Social Council.

USAID. (2011). USAID Country Profile. Property Rights and Resource Governance: Philippines. Retrieved from http://exchange.growasia.org/system/files/USAID_Land_Tenure_Philippines_Profile.pdf

Villanueva, J. (2011). Oil palm expansion in the Philippines. Analysis of land rights, environment and food security issues. In Colchester, M. \& Chao, S. Oil Palm Expansion in South East Asia: trends and implications for local communities and indigenous peoples (pp. 110-216). Moreton-in-Marsh: Forest Peoples Programme and Bogor - West Java: Perkumpulan Sawit Watch. 
White, B., Borras, Jr. S.M., Hall, R., Scoones, I. \& Wolford, W. (2012). The new enclosures: critical perspectives on corporate land deals. The Journal of Peasant Studies 39(3-4), 619-647. https://dx.doi.org/10.1080/ 03066150.2012 .691879

Whitmore, A. (2006). The emperor's new clothes: Sustainable mining? Journal of Cleaner Production 14(3-4), 309-314. https://dx.doi.org/ 10.1016/j.jclepro.2004.10.005

Wiessner, S. (2011). The Cultural Rights of Indigenous Peoples: Achievements and Continuing Challenges. The European Journal of International Law 22, 1, 121-140. https://dx.doi.org/ 10.1093/ejil/chr007

Xanthaki, A. (2003). Land Rights of Indigenous Peoples in South-east Asia. Melbourne J. of International Law, 4(2), 467-496. Retrieved from http://law.unimelb.edu.au/_data/assets/pdf_file/0007/1680361/Xanthaki.pdf

Yengoh, G. T. \& Armah, F. A. (2015). Effects of Large-Scale Acquisition on Food Insecurity in Sierra Leone. Sustainability 7, 9505-9539. https://dx.doi.org/ 10.3390/su7079505

\section{Copyrights}

Copyright for this article is retained by the author(s), with first publication rights granted to the journal.

This is an open-access article distributed under the terms and conditions of the Creative Commons Attribution license (http://creativecommons.org/licenses/by/4.0/). 